\title{
ANALYSIS AND COMPARISON OF THE FUEL PROPERTIES OF BIO-OILS PRODUCED BY CATALYTIC FAST PYROLYSIS OF Tectona grandis
}

\author{
Pious O. OKEKUNLE* \\ Akinola D. OGUNSOLA \\ Oluwapelumi A. BABAYEMI \\ Emmanuel D. ABODUNRIN \\ Olanrewaju M. DARAMOLA
}

Received: 11.12.2020; revised: 02.08.2021; accepted: 13.08.2021

\begin{abstract}
This study analyzed the fuel properties of bio-oils produced by catalytic fast pyrolysis of Tectona grandis in a fixed bed reactor at different temperatures $\left(400-600{ }^{\circ} \mathrm{C}\right)$ and biomass to catalyst $(\mathrm{b} / \mathrm{c})$ weight ratios (90/10 - 60/40). Magnesium oxide (MgO) was used as catalyst. The product yields were determined. Bio-oils were characterized with their elemental composition and their Higher Heating Values (HHVs) as well as their basic fuel properties at maximum bio-oil yields conditions, including viscosity, flash point, moisture content, $\mathrm{pH}$ value and Conradson Carbon Residue (CCR), were determined and compared with those of non-catalytic pyrolysis bio-oils. The maximum yields of bio-oil at 400,500 and $600{ }^{\circ} \mathrm{C}$ were 31.53 , 40.87 and $29.30 \mathrm{wt} . \%$, respectively, obtained at b/c ratios of 70/30, 80/20 and 70/30. Catalytic pyrolysis bio-oils possessed higher carbon and hydrogen but lower oxygen and sulphur contents than non-catalytic pyrolysis bio-oils. The HHVs of catalytic pyrolysis bio-oils $(40.31-42.08 \mathrm{MJ} / \mathrm{kg})$ were higher than those of non-catalytic bio-oils $\left(36.47-36.76 \mathrm{MJ} / \mathrm{kg}\right.$ ). Catalyst reduced the viscosity (at 400 and $\left.500{ }^{\circ} \mathrm{C}\right)$, moisture content and CCR (at 400 and $600{ }^{\circ} \mathrm{C}$ ), and increased the $\mathrm{pH}$ value of bio-oils (at 400 and $600{ }^{\circ} \mathrm{C}$ ). Catalytic pyrolysis deoxygenates and enhances the fuel properties of bio-oils.
\end{abstract}

Keywords: Characterization, Catalyst, Fast pyrolysis, Tectona grandis, Bio-oil, Fuel properties

\section{Tectona grandis' in Katalitik Hızlı Piroliziyle Üretilen Biyo-Yağların Yakıt Özelliklerinin Analizi ve Karşılaştırılması}

Öz: Bu çalışmada, farklı sıcaklıklarda $\left(400-600{ }^{\circ} \mathrm{C}^{\prime} \mathrm{de}\right)$ ve farklı biyokütle/katalizör (b/c) ağırlık oranlarında $(90 / 10$ - 60/40) sabit yataklı bir reaktörde Tectona grandis'in katalitik hızlı pirolizi ile üretilen biyo-yağların yakıt özellikleri incelenmiştir. Katalizör olarak magnezyum oksit (MgO) kullanılmıştır ve ürün verimleri belirlenmiştir. Biyo-yağlar karakterize edilmiştir ve element bileşimleri, yüksek 1sıtma değerleri, maksimum biyo-yağ verimi koşullarındaki temel yakıt özellikleri, viskozite, parlama noktası, nem içeriği, pH değeri ve Conradson karbon kalıntısı (CCR) değerleri incelenmiştir ve katalitik olmayan piroliz biyo-yağların değerleri ile karşılaştırılmıştır. 400, 500 ve $600{ }^{\circ} \mathrm{CC}^{\prime} \mathrm{de}$ ve $70 / 30,80 / 20$ ve $70 / 30 \mathrm{~b} / \mathrm{c}$ oranlarında elde edilen ağırlıça maksimum biyo-yağ verimleri sırasıyla, \%31,53, \% 40,87 ve \% 29,30 olarak bulunmuştur. Katalitik piroliz biyo-yağları, katalitik olmayan piroliz biyo-yağlarından daha yüksek karbon ve hidrojene ancak daha düşük oksijen ve kükürt içeriğine sahip bulunmuştur. Katalitik piroliz biyoyağlarının Yüksek Isıtma Değerleri (HHV) $(40,31$ - 42,08 MJ/kg), katalitik olmayan biyo-yağlardan $(36,47$ - 36,76 MJ/kg) daha yüksek belirlenmiştir. Katalizör, viskoziteyi (400 ve $500{ }^{\circ} \mathrm{C}$ 'de), nem içeriğini ve CCR'yi (400 ve $600{ }^{\circ} \mathrm{C}^{\prime} \mathrm{de}$ ) azaltmıştır ve biyo-yağların pH değerini (400 ve $600^{\circ} \mathrm{C}$ 'de) artırmıştır. Katalitik piroliz, biyo-yağların yakıt özelliklerini geliştirmektedir.

Anahtar Kelimeler: Karakterizasyon, Katalizör, Hızlı piroliz, Tectona grandis, Biyo-yağ, Yakıt özellikleri 


\section{INTRODUCTION}

Advances in global economy and sustainable development have necessitated the need to make energy readily available in the most environmentally friendly way. Energy generation from fossil fuels is no longer business as usual as humans are now well aware of its various consequences on the environment (Thangalazhy-Gopakumar et al., 2010), humans and aquatic lives (Latake et al., 2015). These include acid rain, depletion of the ozone layer, global warming (Zabeti et al., 2012) and destruction of microalgae, to mention a few. Sequel to these, regulations on carbon emissions into the atmosphere have become more stringent than ever. Besides, the depletion of fossil fuel resources suggests that fossils will not be able to meet the ever increasing energy demand in the future (Kraiem et al., 2014).

Renewable energy resources are now being considered as substitutes for fossils. Amongst the promising renewable resources, biomass is seen as a viable option. Although there are thermochemical and biochemical technologies for biomass conversion to energy fuels, thermochemical processes are often preferred. Pyrolysis, one of the thermochemical processes, has been shown to be a viable means for production of solid, liquid and gaseous biofuels, with the liquid fuel accounting for about $70 \%$ of the energy content of the feedstock (Bridgwater and Peacocke, 2000).

However, the liquid fuels (bio-oils) from pyrolysis have high moisture, oxygenated compounds, acidity and viscosity. Besides, they are unstable during storage and are characterized with low H/C ratios (Pütün, 2010). These shortcomings have brought about the use of catalysts in upgrading bio-oils from biomass pyrolysis (Samolada, 2000). Zhou et al. (2013) studied the effect of zinc oxide on the characteristics bio-oil derived from pyrolysis of rice husk in a fixed bed reactor. Pütün et al. (2008) investigated the effect of alumina on the product yields from pyrolysis of Euphorbia rigida biomass sample in inert and steam atmospheres and analysed the compositions of the bio-oil yields. French and Czernik (2010) evaluated the performance of commercial and laboratory-synthesized catalysts on hydrocarbon production during pyrolysis of aspen wood, Avicel PH-105 cellulose and straw lignin. Pütün (2010) studied the effect of magnesium oxide on pyrolysis of cotton seed and compared the yields of asphaltenes, n-pentane solubles, aliphatic sub-fraction, aromatic sub-fraction and polar sub-fraction from non-catalytic and $\mathrm{MgO}$ catalyst-assisted pyrolysis. Güllü (2003) studied the effect of sodium and pottasium carbonate on the yield of liquid products from pyrolysis of hazelnut, tea factory waste, tobacco stalk and yellow pine wood. Onay (2014) studied the effect of $\mathrm{Ni}-\mathrm{Mo} / \gamma$ - alumina catalyst on pyrolysis of Laurel (Laurus nobilis L.) seed in a fixed bed tubular reactor. Samolada et al. (2000) presented an evaluation of some catalysts commonly used for catalytic pyrolysis of biomass. In many of the studies discussed above, the basic fuel properties of the derived bio-oil were not determined.

Qiang et al. (2008) analysed the chemical and physical properties of bio-oil from fast pyrolysis of rice husk and determined the basic fuel properties of the bio-oil. However, the effect of catalyst on these properties was not considered. Mythili et al. (2017) studied the effect of pyrolysis temperature on physicochemical properties of Prosopis juliflora bio-oil but did not also consider the effect of catalyst on these properties. Shah et al. (2012) analysed the physicochemical properties of the bio-oil produced by fast pyrolysis of corn stover and cobs and only reported the proximate and ultimate analyses with modified acid number without considering the effect of catalyst. Lyu et al. (2015) estimated and compared the components of bio-oils from different pyrolysis conditions but did not determine the basic fuel properties, neither was the effect of catalyst considered. Yu et al. (2007) analysed the physical and chemical properties of bio-oil from microwave pyrolysis of corn stover but did not also consider the effect of catalyst on these properties. Several other researchers studied the properties of bio-oils from various biomass materials under different pyrolysis conditions without considering the effect of catalysts (Nanda et al., 2014; Weerachanchai et al., 2007; Garcia-Perez et al., 2007; Chukwuneke et al., 2019; 
Garcìa-Pèrez et al., 2002; Kato et al., 2016). Besides, studies have shown that different feedstocks give different yield patterns and properties of pyrolysis-derived bio-oil (Chukwuneke et al., 2019). Therefore, in this study, the effect of magnesium oxide catalyst on the physicochemical properties of bio-oil from Tectona grandis pyrolysis was studied. The basic fuel properties, including density, viscosity, $\mathrm{pH}$ value, flash point, pour point and Conradson carbon residue of the bio-oil were also determined and compared with those of the bio-oil from non-catalytic experiments.

\section{MATERIALS AND METHODS}

\subsection{Materials}

Tectona grandis sawdust was procured from a sawmill in Ogbomoso, South-Western Nigeria. Magnesium oxide $(\mathrm{MgO})$ catalyst (having $5 \%$ loss on ignition at $1000{ }^{\circ} \mathrm{C}$ ) was procured from a chemical vendor in Ogbomoso, Nigeria.

\subsection{Methods}

\subsubsection{Feedstock Processing}

The procured sawdust sample was sundried for three days in order to reduce its moisture content. After sun drying, it was weighed and bagged in a cellophane bag for it to maintain its moisture content and it was kept at room temperature till when it was used for the experiments.

\subsubsection{Feedstock Characterization}

The biomass sample was characterized with its fixed carbon, volatile mater, moisture and ash by proximate analysis using a thermogravimetric analyzer (TGA) (Model 5E-MAC 6710, Changsha Kaiyuan Instruments Co. Ltd, China). The elemental analysis of the raw sample was done in a CHN analyzer (Leco CHN 2000 elemental analyzer). Sulphur content was determined by a sulphur analyzer (TSHR TS 6000 Total Sulphur Analyzer). The Higher Heating Value (HHV) of the raw sample was estimated by equation 1, according to Sheng and Azevedo (2005), given as

$$
H H V_{\text {raw }}(M J / k g)=-1.3675+0.3137 \times w t . \% C+0.7009 \times w t . \% H+0.0318 \times w t . \% O
$$

\subsubsection{Experimental Setup and Procedure}

Figure 1 shows the exploded view of the pyrolysis unit used for the experiments. The detailed description of this setup has been given elsewhere (Okekunle et al., 2016). Samples with different biomass/catalyst weight ratio (b/c ratio) of 90/10, 80/20, 70/30 and 60/40, thoroughly mixed together, were fed into the crucible, one at a time, and the crucible was covered and fastened with bolts and nuts in preparation for a run. The furnace was then plugged to the mains, pre-set and heated with the aid of an electric heating element to a temperature $50{ }^{\circ} \mathrm{C}$ higher than the desired temperature for pyrolysis in order to compensate for the heat loss during the insertion of the crucible. When the furnace attained the pre-set temperature, it was opened and the crucible was inserted into it. The furnace was covered again and reset to the actual pyrolysis temperature.

This procedure was followed for the pyrolysis temperatures of 400,500 and $600{ }^{\circ} \mathrm{C}$ and a residence time of $15 \mathrm{~min}$. After each run, the liquid and char yields were weighed and expressed in percentages of the weight of the initial sample while gas yield was obtained by mass balance.

\subsection{Bio-oil Characterization}

\subsubsection{Ultimate Analysis}

The elemental analysis of the bio-oils was done with the same equipment used for the feedstock. The sulphur content of the bio-oils was also determined by a Sulphur analyzer (TSHR TS 6000 Total Sulphur Analyzer). The Higher Heating Values (HHVs) of the bio-oils were 
Okekunle P.O. ve ark: Analys. Comp. of the Fuel Prop. of Bio-Oil Prod. Cataly. Fast Pyrol. Tectona. grdis.

determined using modified Dulong's formula according to Theegala and Midgett (2012), given by equation 2 .

$$
H H V_{\text {bio-oil }}(M J / k g)=\frac{33.5 \times w t . \% C}{100}+\frac{142.3 \times w t . \% H}{100}-\frac{15.4 \times w t . \% O}{100}
$$

\subsubsection{Fuel Characterization of Bio-oils}

The fuel properties of the bio-oils were determined in accordance with standard methods. Viscosity was determined according to ASTM D 445. The flash point was determined according to ASTM D 1310. The pour point and Conradson Carbon Residue (CCR) were determined according to ASTM D 5853 and ASTM D 189, respectively. The pH value was determined with the aid of a pH meter (Hanna Model HI 8424). Moisture content was determined according to ASTM E 203. Ash content was estimated according to ASTM D 482.

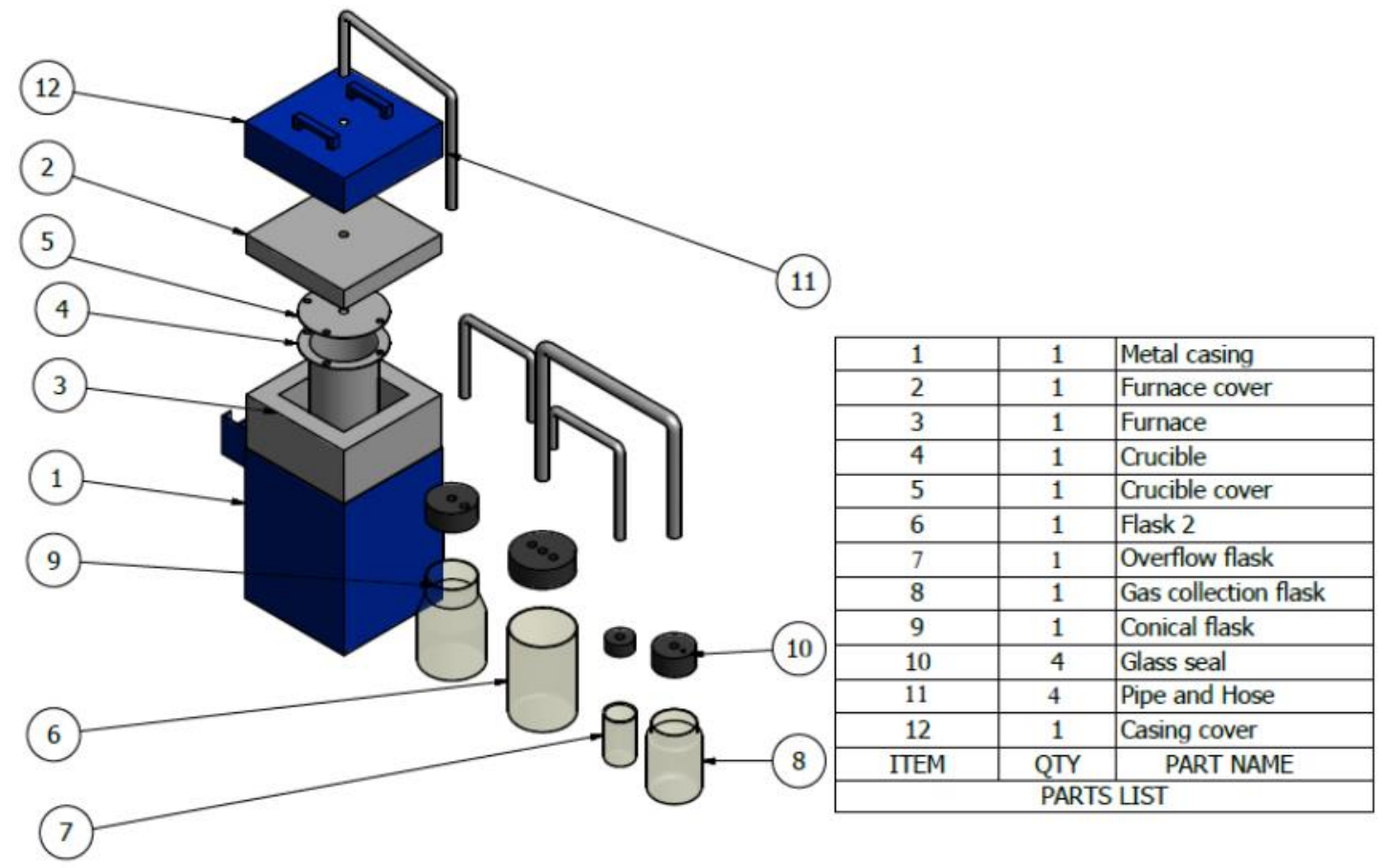

Figure 1:

The exploded view of the pyrolysis unit

\section{RESULTS AND DISCUSSION}

\subsection{Physicochemical Properties of Tectona grandis}

The physicochemical properties of the feedstock are presented in Table 1. Proximate analysis showed a high percentage of volatile matter (78.42\%), low moisture content $(9.00 \%)$ and ash (0.58). Elemental analysis revealed the percentage of carbon (50.82\%), hydrogen (5.88\%) and oxygen $(42.80 \%)$. The detailed analysis of the physicochemical properties of the feedstock has been given elsewhere (Okekunle et al., 2021). 


\subsection{Products Yields}

Table 2 shows the yields of char, bio-oil and gas from the catalytic pyrolysis at different b/c ratios and temperatures. From the table, the highest yields of char $(52.45 \%)$, bio-oil $(40.87 \%)$ and gas $(46.95 \%)$ were obtained at $400{ }^{\circ} \mathrm{C}\left(60 / 40 \mathrm{~b} / \mathrm{c}\right.$ ratio), $500{ }^{\circ} \mathrm{C}\left(80 / 20 \mathrm{~b} / \mathrm{c}\right.$ ratio) and $400{ }^{\circ} \mathrm{C}(80 / 20$ $\mathrm{b} / \mathrm{c}$ ratio), respectively, while the lowest yields of char $(25.65 \%)$, bio-oil $(10.27 \%)$ and gas (21.83\%) were respectively obtained at $600{ }^{\circ} \mathrm{C}\left(90 / 10 \mathrm{~b} / \mathrm{c}\right.$ ratio), $500{ }^{\circ} \mathrm{C}(60 / 40 \mathrm{~b} / \mathrm{c}$ ratio) and 400 ${ }^{\circ} \mathrm{C}(60 / 40 \mathrm{~b} / \mathrm{c}$ ratio).

Table 1: Physicochemical properties of Tectona grandis

\begin{tabular}{|c|c|c|}
\hline Proximate analysis (wt.\%) & Elemental analysis (wt.\%) & Atomic ratio (-) \\
\hline Moisture content 9.00 & Carbon & $\begin{array}{ll}\mathrm{H} / \mathrm{C} & 1.3787\end{array}$ \\
\hline Ash content & Hydrogen & 0.6322 \\
\hline Volatile matter & Nitrogen & 0.0047 \\
\hline \multirow[t]{3}{*}{$\begin{array}{ll}\text { Fixed carbon } \quad 12.00\end{array}$} & Oxygen & \\
\hline & Sulphur & \\
\hline & HHV (MJ/kg) - 20.1 & \\
\hline
\end{tabular}

Source: Okekunle et al. (2021)

Table 2: Char, bio-oil and gas yields from catalytic pyrolysis of Tectona grandis

\begin{tabular}{|c|c|c|c|c|c|c|c|c|c|}
\hline $\begin{array}{r}\mathrm{B} / \mathrm{C} \\
\text { ratio }\end{array}$ & \multicolumn{3}{|c|}{ Char yield (wt.\%) } & \multicolumn{3}{c|}{ Bio-oil yield (wt.\%) } & \multicolumn{3}{c|}{ Gas yield (wt.\%) } \\
\hline & $400{ }^{\circ} \mathrm{C}$ & $500{ }^{\circ} \mathrm{C}$ & $600{ }^{\circ} \mathrm{C}$ & $400{ }^{\circ} \mathrm{C}$ & $500{ }^{\circ} \mathrm{C}$ & $600{ }^{\circ} \mathrm{C}$ & $400{ }^{\circ} \mathrm{C}$ & $500{ }^{\circ} \mathrm{C}$ & $600{ }^{\circ} \mathrm{C}$ \\
\hline $90 / 10$ & 36.29 & 32.30 & 25.69 & 26.13 & 28.89 & 28.58 & 37.58 & 38.81 & 45.73 \\
\hline $80 / 20$ & 28.29 & 32.89 & 33.49 & 24.76 & 40.87 & 27.36 & 46.95 & 26.24 & 39.15 \\
\hline $70 / 30$ & 35.49 & 37.35 & 39.52 & 31.53 & 29.61 & 29.35 & 32.98 & 33.04 & 31.13 \\
\hline $60 / 40$ & 52.45 & 42.63 & 42.49 & 25.72 & 10.27 & 17.05 & 21.83 & 47.10 & 40.46 \\
\hline
\end{tabular}

\subsection{Elemental Analysis of Bio-oils}

Table 3 shows the elemental composition of the bio-oils from catalytic pyrolysis at different temperatures and $\mathrm{b} / \mathrm{c}$ ratios compared with those of the bio-oils from non-catalytic experiments. As shown in the table, the bio-oils derived from catalytic pyrolysis are richer in carbon and hydrogen but leaner in oxygen than those obtained from non-catalytic (NC) runs at the same temperatures.These results are in agreement with the findings of Pütün (2010), who reported higher percentages of carbon (77.62 wt.\%) and hydrogen (12.15 wt.\%) but a lower oxygen percentage (4.9 wt.\%) for catalytic pyrolysis bio-oil compared to the values obtained for non- 
catalytic pyrolysis bio-oil (C - 74.24 wt.\%, H - 11.39 wt.\% and O - 9.56 wt.\%). Zhou et al. (2013) also reported higher percentages of carbon $(49.73 \mathrm{wt} . \%)$ and hydrogen $(12.57 \mathrm{wt} . \%)$ with a lower oxygen percentage (35.62 wt.\%) for bio-oil from catalytic pyrolysis than the values obtained for non-catalytic pyrolysis bio-oil (C - 49.20 wt.\%, H - 11.65 wt.\%, O - 36.78 wt.\%). Carbon and hydrogen enrichment with reduction in oxygen in the bio-oils from catalytic pyrolysis suggests they have better calorific values than those from non-catalytic experiments. This fact is substantiated by the HHVs presented in Table 3 . These results have also shown that catalysts help in deoxygenating bio-oils (Pütün, 2010). Oxygen reduction in catalytic pyrolysis bio-oils will improve their stability and enhance their upgrading to hydrocarbons (Shah et al., 2012). This is because oxygen in bio-oil has been identified as a source of bio-oil instability (Bardalai and Mahanta, 2015) and also, bio-oil upgrading to hydrocarbons will require oxygen removal (Shah et al., 2012).

Moreover, Table 3 also shows that the presence of $\mathrm{MgO}$ catalyst reduced the percentage of sulphur in catalytic pyrolysis bio-oils $(0.05-0.07 \%)$ compared to the values for bio-oils from non-catalytic experiments $(0.11-0.21 \%)$. This implies that Sox emissions from the combustion of catalytic pyrolysis bio-oils will be much lower than those from non-catalytic pyrolysis bio-oils. Therefore, bio-oils from catalytic pyrolysis could be more environmentally friendly. $\mathrm{H} / \mathrm{C}$ and $\mathrm{O} / \mathrm{C}$ ratios for bio-oils from catalytic pyrolysis are respectively higher and lower than those for noncatalytic pyrolysis bio-oils. These results are in agreement with the findings of Pütün (2010) and Zhou et al. (2013), who reported higher $\mathrm{H} / \mathrm{C}$ and lower $\mathrm{O} / \mathrm{C}$ ratios for bio-oils from catalytic pyrolysis compared to the values obtained for bio-oils derived from non-catalytic pyrolysis.

Table 3: Elemental composition and HHVof bio-oils obtained at different temperatures and b/c ratios

\begin{tabular}{|c|c|c|c|c|c|c|c|c|c|c|}
\hline \multirow{2}{*}{$\begin{array}{l}\mathrm{T} \\
\left({ }^{\circ} \mathrm{C}\right) \\
\end{array}$} & \multirow{2}{*}{$\begin{array}{l}\mathrm{B} / \mathrm{C} \\
\text { ratio (-) }\end{array}$} & \multicolumn{5}{|c|}{ Element (wt.\%) } & \multicolumn{3}{|c|}{$\begin{array}{l}\text { Atomic } \\
\text { ratio (-) }\end{array}$} & \multirow{2}{*}{$\begin{array}{l}\mathrm{HHV} \\
(\mathrm{MJ} / \mathrm{kg})\end{array}$} \\
\hline & & C & $\mathrm{H}$ & $\mathrm{N}$ & $\mathrm{O}$ & S & $\mathrm{H} / \mathrm{C}$ & $\mathrm{O} / \mathrm{C}$ & $\mathrm{N} / \mathrm{C}$ & \\
\hline \multirow[t]{5}{*}{400} & $90 / 10$ & 81.36 & 10.90 & 3.24 & 4.52 & 0.07 & 1.596 & 0.042 & 0.034 & 42.07 \\
\hline & $80 / 20$ & 81.10 & 10.98 & 3.26 & 4.60 & 0.06 & 1.613 & 0.043 & 0.034 & 42.08 \\
\hline & $70 / 30$ & 80.02 & 10.88 & 4.48 & 4.80 & 0.06 & 1.620 & 0.045 & 0.048 & 41.55 \\
\hline & $60 / 40$ & 80.26 & 10.90 & 4.24 & 4.55 & 0.07 & 1.618 & 0.043 & 0.045 & 41.70 \\
\hline & $\mathrm{NC}^{*}$ & 75.82 & 8.98 & 4.29 & 10.80 & 0.11 & 1.410 & 0.110 & 0.049 & 36.52 \\
\hline \multirow[t]{5}{*}{500} & $90 / 10$ & 80.30 & 9.98 & 5.27 & 4.60 & 0.05 & 1.481 & 0.043 & 0.056 & 40.39 \\
\hline & $80 / 20$ & 80.22 & 9.96 & 5.30 & 4.57 & 0.05 & 1.479 & 0.043 & 0.057 & 40.34 \\
\hline & $70 / 30$ & 80.22 & 9.98 & 4.29 & 4.88 & 0.07 & 1.482 & 0.046 & 0.046 & 40.32 \\
\hline & $60 / 40$ & 80.46 & 9.96 & 5.24 & 4.50 & 0.06 & 1.475 & 0.042 & 0.056 & 40.43 \\
\hline & $\mathrm{NC}^{*}$ & 76.50 & 8.96 & 4.24 & 10.50 & 0.11 & 1.400 & 0.100 & 0.048 & 36.76 \\
\hline \multirow[t]{5}{*}{600} & $90 / 10$ & 80.40 & 9.93 & 4.26 & 4.60 & 0.06 & 1.472 & 0.043 & 0.045 & 40.36 \\
\hline & $80 / 20$ & 80.52 & 9.98 & 4.28 & 4.65 & 0.07 & 1.477 & 0.043 & 0.046 & 40.46 \\
\hline & $70 / 30$ & 80.36 & 9.90 & 4.24 & 4.52 & 0.05 & 1.468 & 0.042 & 0.045 & 40.31 \\
\hline & $60 / 40$ & 81.20 & 9.94 & 4.26 & 4.60 & 0.05 & 1.459 & 0.043 & 0.045 & 40.64 \\
\hline & $\mathrm{NC}^{*}$ & 75.80 & 8.93 & 4.46 & 10.60 & 0.21 & 1.400 & 0.110 & 0.050 & 36.47 \\
\hline
\end{tabular}

NC - Non-catalytic pyrolysis, * Data for NC were obtained from Okekunle et al. (2021). 


\subsection{Basic Fuel Properties of Bio-oil}

The basic fuel properties of the bio-oils from catalytic pyrolysis at the b/c ratios where maximum yields were obtained for all the considered temperatures are compared with those of the bio-oils from non-catalytic experiments at the same temperatures. The maximum bio-oil yields from catalytic pyrolysis at 400 (31.53 wt.\%), 500 (40.87 wt. \%) and $600{ }^{\circ} \mathrm{C}(29.35 \mathrm{wt} . \%)$ were obtained at b/c ratios of 70/30,80/20, and 70/30, respectively.

\subsection{1. pH Value}

Figure 2 shows the $\mathrm{pH}$ values of the bio-oils from catalytic pyrolysis at optimum $\mathrm{b} / \mathrm{c}$ ratio for bio-oil yield at 400, 500 and $600{ }^{\circ} \mathrm{C}$ compared with those of the bio-oils from non-catalytic experiments at the same temperatures. As shown in the figure, $\mathrm{MgO}$ catalyst increased the $\mathrm{pH}$ values of the bio-oils at 400 and $600{ }^{\circ} \mathrm{C}$. These results are in agreement with the findings of Shadangi and Mohanty (2014 a\&b), who reported increase in $\mathrm{pH}$ values of the bio-oils from catalytic pyrolysis of Karanja and Niger seed as compared to those of bio-oils from non-catalytic pyrolysis of the same biomass materials. At $500{ }^{\circ} \mathrm{C}$, however, the $\mathrm{pH}$ value of the bio-oil from catalytic pyrolysis was lower than that of the bio-oil from non-catalytic experiment. This may be linked to the difference in $b / c$ ratio that gave the optimum yield of bio-oil at this temperature. Lower $\mathrm{pH}$ values make bio-oils acidic, causing damages to internal combustion engines when such bio-oils are used. The $\mathrm{pH}$ values of the catalytic pyrolysis bio-oils are within the range (2.0 - 3.8) reported for other bio-oils (Garcì-Pèrez et al., 2002). Catalytic esterification can be used to further increase the $\mathrm{pH}$ values of the bio-oils (Wang, 2013).

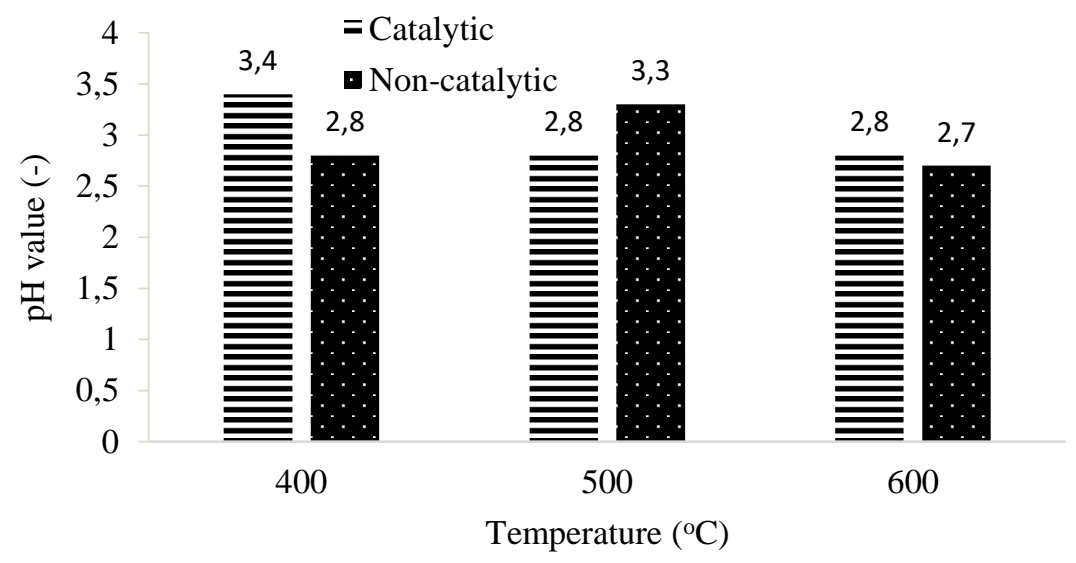

Figure 2:

Comparison of $p H$ values of bio-oils from catalytic and non-catalytic pyrolysis

\subsubsection{Viscosity}

Figure 3 shows the viscosities of the bio-oils from catalytic pyrolysis at optimum $\mathrm{b} / \mathrm{c}$ ratio for bio-oil yield at 400,500 and $600{ }^{\circ} \mathrm{C}$ compared with those of the bio-oils from non-catalytic experiments at the same temperatures. As shown in the figure, the presence of catalyst reduced the viscosity of bio-oil at 400 and $500{ }^{\circ} \mathrm{C}$. Shadangi and Mohanty $(2014 \mathrm{a} \& \mathrm{~b})$ have also reported reduction in viscosity of bio-oils obtained from catalytic pyrolysis compared to the values obtained for bio-oils from non-catalytic pyrolysis of the same feedstock. One of the main concerns in the use of bio-oil as fuel in diesel engines is high viscosity, which poses a challenge during atomization (Shadangi, 2014a). Catalytic pyrolysis, with the right process conditions and b/c ratio, can help address this concern. At $600{ }^{\circ} \mathrm{C}$, however, the viscosity of catalytic pyrolysis bio-oil was higher than that of non-catalytic by $1 \mathrm{mPa}$.s. This may be attributed to repolymerization of lighter organics at this temperature. The viscosities of the catalytic pyrolysis bio-oils obtained in this 
Okekunle P.O. ve ark: Analys. Comp. of the Fuel Prop. of Bio-Oil Prod. Cataly. Fast Pyrol. Tectona. grdis.

study are much lower than those reported by Yu et al. (2007), and Oyebanji and Ololade (2017), which were 185 and $53.25 \mathrm{mPa}$.s, respectively.

\subsubsection{Flash Point}

Figure 4 shows the comparison of the flash points of the bio-oils obtained from catalytic pyrolysis with those of the bio-oils from non-catalytic experiments. As shown in the figure, catalytic pyrolysis bio-oils have lower flash points than those from non-catalytic experiments, and are also lower than that of petroleum diesel $\left(58.5^{\circ} \mathrm{C}\right)$ (Khan et al., 2016). This implies that the catalytic pyrolysis bio-oils obtained in this study are more flammable than petroleum diesel. Therefore, for safety in handling and transportation, increasing the flash points of the bio-oils by removing lighter organic compounds may be necessary.
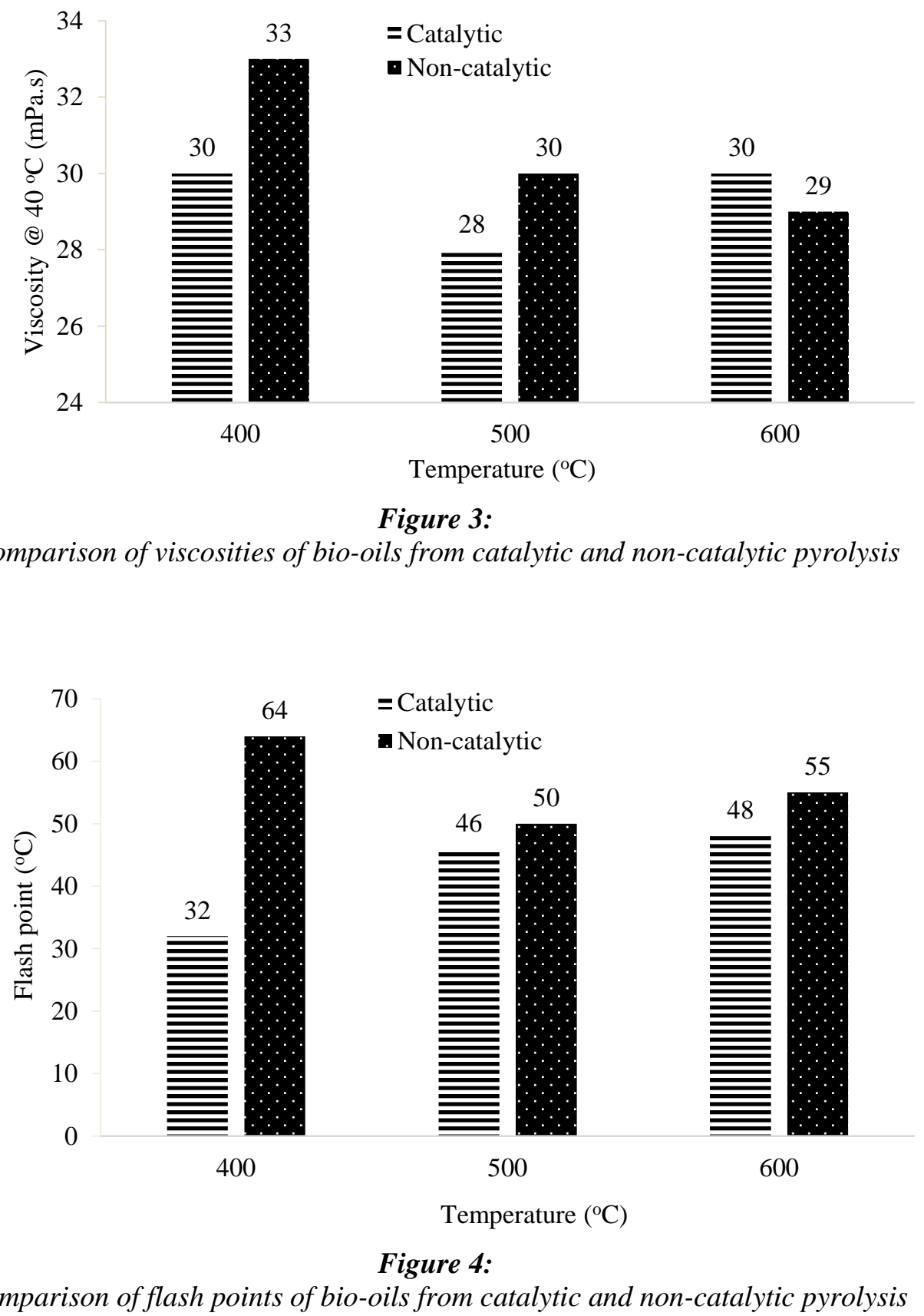


\subsubsection{Pour Point}

Figure 5 shows the pour points of catalytic pyrolysis bio-oils compared with those of the noncatalytic pyrolysis bio-oils. As shown in the figure, the presence of catalyst has no effect on the pour point at pyrolysis temperatures of 400 and $600{ }^{\circ} \mathrm{C}$. At $500{ }^{\circ} \mathrm{C}$, however, the use of catalyst reduced the pour point of bio-oil from -25 to $-28{ }^{\circ} \mathrm{C}$. The pour points of bio-oils from catalytic pyrolysis obtained in this study are lower than those reported by Weerachanchai et al. (2007) (-17 to $1{ }^{\circ} \mathrm{C}$ ) and Chukwuneke et al. (2019) $\left(13.5^{\circ} \mathrm{C}\right)$. Since pour point is the temperature below which a liquid loses its flow characteristics, the bio-oils obtained in this study, therefore, are not suitable for use in extremely cold countries.

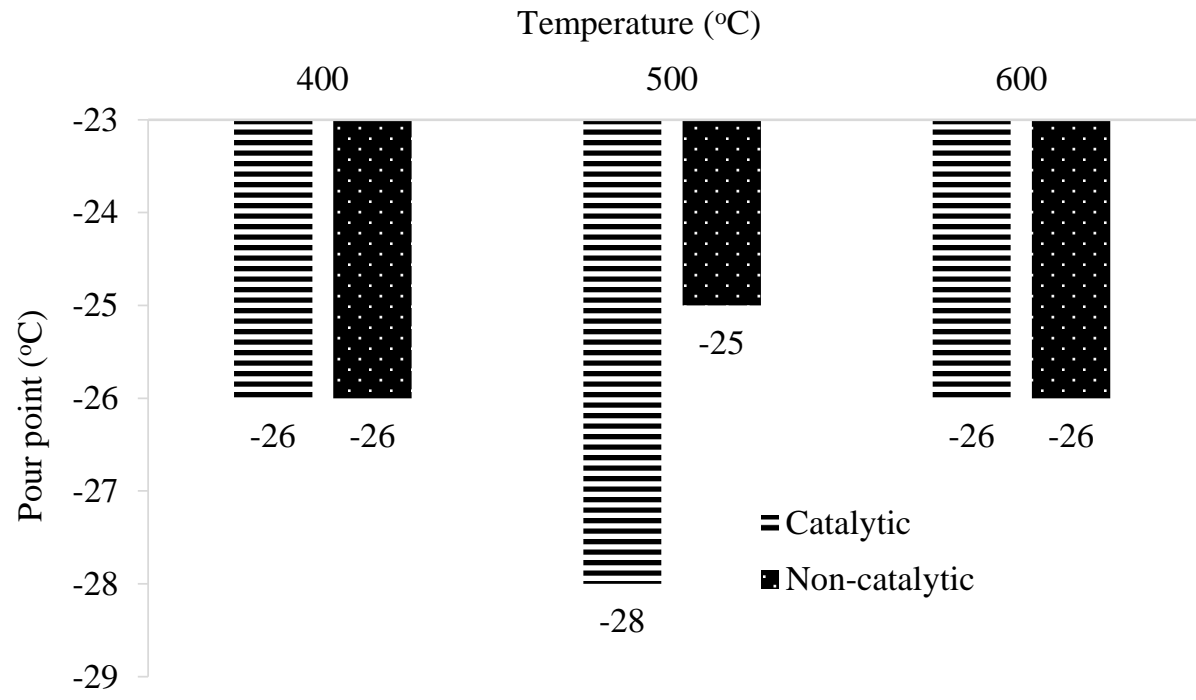

Figure 5:

Comparison of pour points of bio-oils from catalytic and non-catalytic pyrolysis

\subsubsection{Moisture Content}

Figure 6 shows the comparison of the moisture content of the bio-oils produced by catalytic and non-catalytic pyrolysis. As shown in the figure, the moisture content in catalytic pyrolysis bio-oils was higher at $500{ }^{\circ} \mathrm{C}$ but lower at 400 and $600{ }^{\circ} \mathrm{C}$ than in non-catalytic pyrolysis bio-oils. Shadangi and Mohanty ( 2014 a \& b) reported a higher moisture content in catalytic pyrolysis biooils while Zhou et al. (2013) reported a lower value than in non-catalytic pyrolysis bio-oils. Many factors can be responsible for these different observations, including the type of feedstock, the catalyst used, the temperature of pyrolysis as well as the feed to catalyst ratio. In this study, the moisture content of the bio-oils from catalytic and non-catalytic experiments were not significantly different at 400 and $500{ }^{\circ} \mathrm{C}$. At $600{ }^{\circ} \mathrm{C}$, however, there was a reduction from $15.8 \%$ to $13 \%$ with the use of $\mathrm{MgO}$ catalyst (b/c ratio of 70/30). 
Okekunle P.O. ve ark: Analys. Comp. of the Fuel Prop. of Bio-Oil Prod. Cataly. Fast Pyrol. Tectona. grdis.

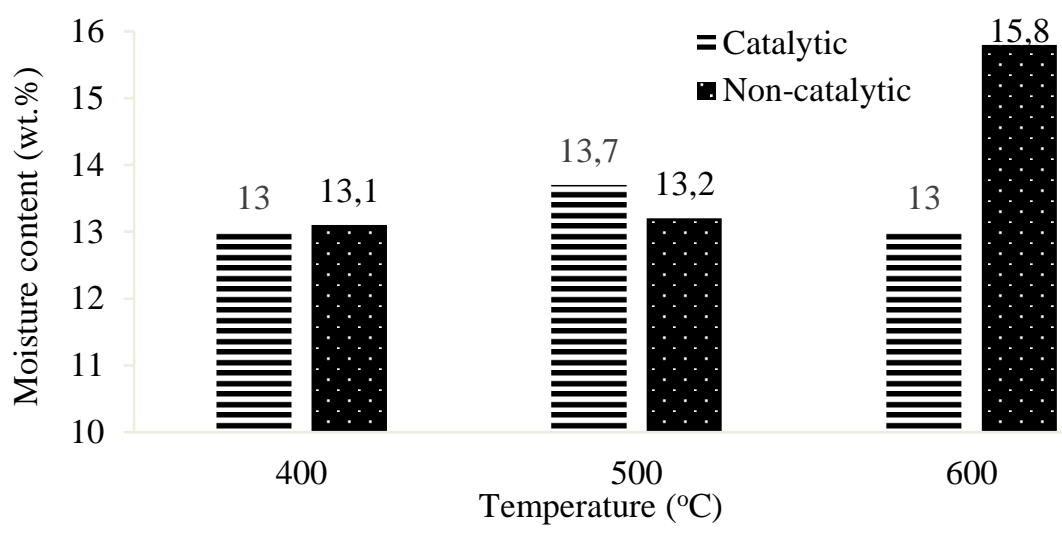

Figure 6:

Comparison of moisture content of bio-oils from catalytic and non-catalytic pyrolysis

\subsubsection{Conradson Carbon Residue (CCR)}

Figure 7 shows the comparison of the CCR of the bio-oils from catalytic and non-catalytic pyrolysis. Carbon residue is a measure of the coke-forming tendencies of fuel oils. From Figure 7 , it is interesting to note that the CCR is the same for all the catalytic pyrolysis bio-oils at all temperatures. This may be due to the fact that the data presented are for the $\mathrm{b} / \mathrm{c}$ ratios yielding maximum bio-oil at all the temperatures considered. Beisdes, the figure also shows that the CCR for the catalytic pyrolysis bio-oils is lower than the values obtained for non-catalytic pyrolysis bio-oils at 400 and $600{ }^{\circ} \mathrm{C}$. This implies that at these temperatures and $\mathrm{b} / \mathrm{c}$ ratios for maximum yield of bio-oil, the formation of heavy structures that are difficult to evaporate was reduced. The values of CCR for both catalytic and non-catalytic bio-oils are lower than those reported for other bio-oils (18 - 23 wt.\%) (Garcia-Pèrez et al., 2002) but higher than the values specified for gasoline $(\leq 0.2$ wt.\%) and diesel $((\leq 0.3 \mathrm{wt} . \%)$ according to NF EN 590 and NF EN 228, respectively (Anouti et al., 2016). The use of polar solvents can be helpful in extracting complex polar heavy structures, thereby reducing the CCR values of the bio-oils (Anouti et al., 2016).

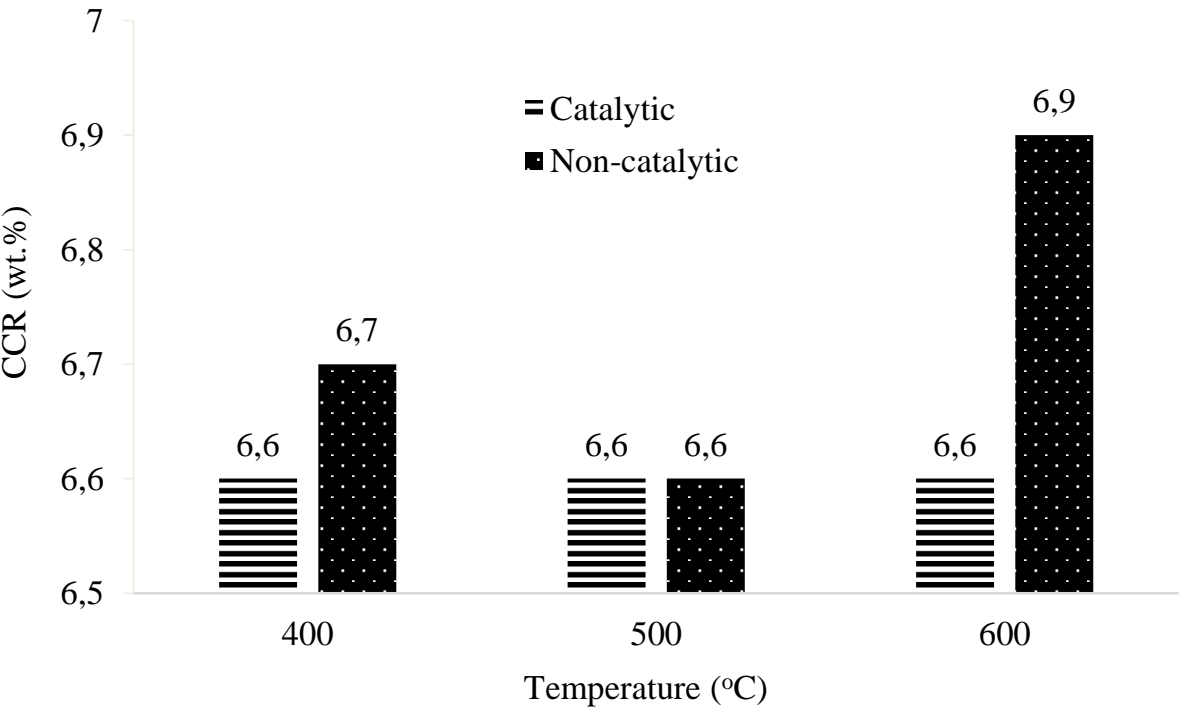

Figure 7:

Comparison of carbon residue of bio-oils from catalytic and non-catalytic pyrolysis 


\section{CONCLUSION}

The fuel properties of bio-oils from catalytic pyrolysis (with $\mathrm{MgO}$ as catalyst) of Tectona grandis at different temperatures and $\mathrm{b} / \mathrm{c}$ ratios have been analyzed and compared with those of non-catalytic pyrolysis bio-oils. The maximum yield of bio-oil at 400 (31.53 wt.\%), 500 (40.87 wt. $\%)$ and $600{ }^{\circ} \mathrm{C}(29.30 \mathrm{wt} . \%)$ were obtained at b/c ratios of 70/30, 80/20 and 70/30, respectively. Elemental analysis showed that catalytic pyrolysis bio-oils are richer in carbon and hydrogen but leaner in oxygen and sulphur than non-catalytic bio-oils. The calorific values of catalytic pyrolysis bio-oils are therefore higher than those of non-catalytic. The use of $\mathrm{MgO}$ as catalyst in pyrolysis improved the fuel properties of bio-oils by reducing their viscosity (at 400 and $500{ }^{\circ} \mathrm{C}$ ), carbon residue and moisture content (at 400 and $600{ }^{\circ} \mathrm{C}$ ), and increasing $\mathrm{pH}$ values (at 400 and $600{ }^{\circ} \mathrm{C}$ ) as well as their $\mathrm{HHV}$ at all the temperatures considered.

\section{CONFLICT OF INTEREST}

Authors approve that to the best of their knowledge, there is not any conflict of interest or common interest with an institution/organization or a person that may affect the review process of the paper

\section{AUTHOR CONTRIBUTION}

Pious O. Okekunle determined the concept and/or design the process of the research. Pious O. Okekunle and Oluwapelumi A. Babayemi managed the concept and design process of the research. Emmanuel D. Abodunrin and Olanrewaju M. Daramola handled data collection. Pious O. Okekunle and Akinola D. Ogunsola were responsible for data analysis and interpretation of the results. Pious O. Okekunle, Akinola D. Ogunsola, Oluwapelumi A. Babayemi, Emmanuel D. Abodunrin and Olanrewaju M. Daramola worked on preparation of the manuscript. Pious O. Okekunle handled critical analysis of the intellectual content. Pious O. Okekunle, Akinola D. Ogunsola, Oluwapelumi A. Babayemi, Emmanuel D. Abodunrin and Olanrewaju M. Daramola are responsible for the final approval and full responsibility.

\section{REFERENCES}

1. Anouti, S., Haarlemmer, G., Déniel, M. and Roubaud, A. (2016) Analysis of physicochemical properties of bio-oil from hydrothermal liquefaction of blackcurrant pomace, Energy \& Fuels, 30(1), $398-406$.

2. Bardalai, M. and Mahanta, D.K. (2015) A review of physical properties of biomass pyrolysis oil, International Journal of Renewable Energy Research, 5(1), 277 - 286.

3. Bridgwater, A.V. and Peacocke, G.V.C. (2000) Fast pyrolysis process for biomass, Renewable and Sustainable Energy Reviews, 4, 1- 73.

4. Chukwuneke, J.L., Ewulonu, M.C., Chukwujike, I.C. and Okolie, P.C. (2019) Physicochemical analysis of pyrolyzed bio-oil from swietenia macrophylla (mahogany) wood, Heliyon, 5(6), 2019, accessed May 21, 2020, from https://doi.org/10.1016/j.heliyon.2019.e01790.

5. French, R. and Czernik, S. (2010) Catalytic pyrolysis of biomass for biofuels production, Fuel Processing Technology, 91, 25 - 32.

6. Garcia-Perez, M., Adams, T.T., Goodrum, J.W., Geller, D.P. and Das, K.C. (2007). Production and fuel properties of pine chip bio-oil/biodiesel blends, Energy \& Fuels, 21, 2363 -2372 . 
Okekunle P.O. ve ark: Analys. Comp. of the Fuel Prop. of Bio-Oil Prod. Cataly. Fast Pyrol. Tectona. grdis.

7. Garcìa-Pèrez, M., Chaala, A. and Roy, C. (2002) Vacuum pyrolysis of sugarcane bagasse, Journal of Analytical and Applied Pyrolysis, (65), 111 - 136.

8. Güllü D. (2003) Effect of catalyst on yield of liquid products from biomass via pyrolysis, Energy Sources, 25(8), 753 - 765.

9. Kato, Y. Enomoto, R., Akazawa, M. and Kojima, Y. (2016) Characterization of Japanese cedar bio-oil produced using a bench-scale auger pyrolyzer, Springer Plus, 5, 1- 11.

10. Khan, M.Z.H., Sultana, M., Al-Mamum, M.R. and Hasan, M.R., Pyrolytic waste oil and its diesel blend: fuel characterization, Journal of Environmental and Public Health, 2016, accessed May 10, 2020, from https://doi.org/10.1155/2016/7869080.

11. Kraiem, T., Hassen-Trabelsi, A. B., Naoui, S. and Belayouni, H. (2014). Characterization of syngas and bio-char: co-products from pyrolysis of waste fish fats, The Fifth International Renewable Energy Congress, IREC 2014, March 25 - 27, Hammamet, Tunisia.

12. Latake, P.T., Pawar, P. and Ranveer, A.C. (2015) The greenhouse effect and its impacts on environment, International Journal of Innovative Research and Creative Technology, 1(3), $333-337$.

13. Lyu, G., Wu, S. and Zhang, H. (2015) Estimation and comparison of bio-oil components from different pyrolysis conditions, Frontiers in Energy Research, 3(28), 1- 11.

14. Mythili, R., Subramanian, P. and Uma, D. (2017) Physicochemical properties of the bio-oil from Prosopis juliflora in fluidized-bed reactor, Energy Sources, Part A: Recovery, Utilization, and Environmental Effects, 39(8), 843 - 849.

15. Nanda, S., Mohanty, P., Kozinski, J.A. and Dalai, A.K. (2014) Physico-chemical properties of bio-oils from pyrolysis of lignocellulosic biomass with high and slow heating rate, Energy and Environment Research, 4(3), 21 - 32.

16. Okekunle, P.O., Itabiyi, O.E., Adetola, S.O., Alayande, I.O., Ogundiran, H.O. and Odeh, K.G. (2016) Biofuel production by pyrolysis of cassava peel in a fixed bed reactor, International Journal of Energy for a Clean Environment, 17(1), 57 - 65.

17. Okekunle, P.O., Ogunsola, A.D., Babayemi, O.A., Abodunrin, E.D. and Daramola, O.M. (2021). Fuel characterization of bio-oil from fast pyrolysis of Tectona grandis in a fixed bed reactor at different temperatures $\left(400-700{ }^{\circ} \mathrm{C}\right)$, International Journal of Energy for a Clean Environment, 22(3), 1 - 14.

18. Onay, Ö. (2014) Effects of catalyst on pyrolysis of Laurel (Laurus Nobilis L.) seed in a fixed bed tubular reactor, Chemical Engineering Transactions, 37, 127 - 132.

19. Oyebanji, J.A. and Ololade, Z.S. (2017) Fast Pyrolysis of Tectona grandis Wood for Bio-oil: Characterization and Bactericidal Potentials, Global Journal of Researches in Engineering: A Mechanical and Mechanics Engineering, 17(1), 31 - 37.

20. Pütün, E.(2010) Catalytic pyrolysis of biomass: Effects of pyrolysis temperature, sweeping gas flow rate and $\mathrm{MgO}$ catalyst, Energy, 35, $2761-2766$.

21. Pütün, E., Ateş, F. and Pütün, A.E. (2008) Catalytic pyrolysis of biomass in inert and steam atmospheres, Fuel, 87, $815-824$.

22. Qiang, L., Xu-lai, Y. and Xi-feng, Z. (2008) Analysis on chemical and physical properties of bio-oil pyrolyzed from rice husk, Journal of Analytical and Applied Pyrolysis, 82, 191 - 198.

23. Samolada, M.C., Papafotica, A. and Vasalos, I.A. (2000) Catalyst evaluation for catalytic biomass pyrolysis, Energy \& Fuels, 14, $1161-1167$. 
24. Shadangi, K.P. and Mohanty, K. (2014a) Thermal and catalytic pyrolysis of Karanja Seed to produce liquid fuel, Fuel, 115, $434-442$.

25. Shadangi, K.P. and Mohanty, K. (2014b) Production and characterization of pyrolytic oil by catalytic pyrolysis of Niger seed, Fuel, 126, $109-115$.

26. Shah, A., Darr, M.J., Dalluge, D., Medic, D. Webster, K. and Brown, R.C. (2012) Physicochemical properties of bio-oil and biochar produced by fast pyrolysis of stored singlepass corn stover and cobs, Bioresource Technology, 125, 348 - 352.

27. Thangalazhy-Gopakumar, S., Adhikari, S., Ravindran, H., Gupta, R.B., Fasina, O., Tu, M. and Fernando, S.D. (2010) Physiochemical properties of bio-oil produced at various temperatures from pine wood using an auger reactor, Bioresource Technology, 101, 8389 8395.

28. Wang S. (2013) High Efficiency Separation of Bio-oil. In M.D. Matovic (Ed.), Biomass Now - Sustainable Growth and Use (pp. 401-418). London: IntechOpen. https://doi.org/10.5772/51423.

29. Weerachanchai, P., Tangsathitkulchai, C. and Tangsathitkulchai, M. (2007) Fuel properties and chemical compositions of bio-oils from biomass pyrolysis, SAE Technical Paper 200101-2024, 2007, https://doi.org/10.4271/2007-01-2024.

30. Yu, F., Deng, S., Chen, P., Liu, Y., Wan, Y., Olson, A., Kittleson, D. and Ruan, R. (2007) Physical and chemical properties of bio-oils from microwave pyrolysis of corn stover, Applied Biochemistry and Biotechnology, 136 - 140, 957 - 970.

31. Zabeti, M., Nguyen, T.S., Lefferts, L., Heeres, H.J. and Seshan, K. (2012) In situ catalytic pyrolysis of lignocellulose using alkali-modified amorphous silica alumina, Bioresource Technology, 118, $374-381$.

32. Zhou, L., Yang, H., Wu, H., Wang, M. and Cheng, D. (2013) Catalytic pyrolysis of rice husk by mixing with zinc oxide: Characterization of bio-oil and its rheological behaviour, Fuel Processing Technology, 106, $385-391$. 
